\title{
Yoksulluğa Hak Temelli Yaklaşım
}

\author{
HICRAN ATATANIR* \\ hatatanir@gmail.com \\ ORCID ID: 0000-0002-0938-4245
}

\author{
KASIM KARATAŞ** \\ kkaratas@hacettepe.edu.tr \\ ORCID ID: 0000-0002-4817-9981
}

Öz: Yoksulluk insanca yaşama hakkının ihlalidir ve varlığını 'kalıcı eşitsizliklerin' korunması ile sürdürür. Günümüz tüketim toplumu pratiğinde asgari bir mal-hizmet sepetini karşılayacak gelire sahip olmayan insanların olduğu gibi, aşırı tüketim nedeniyle sağlık sorunları yaşayan insanların da yaşam hakkı risk altındadır. Küreselleşme süreci ile etki alanı genişleyen neoliberalizm insanları ve yaşamlarını hızla dönüşı̈̈rürken derinleşen eşitsizlikler, her insanın onur ve haysiyetine yaraşır bir hayat sürme hakkını tehdit etmektedir. Yoksul kitlelerin haklarını kullanabilen, savunabilen ve geliştirebilen bireyler olarak toplumsal yaşamda hak ettikleri yeri almaları için atılması gereken adımlar insanlı ailesini ve geleceğini, doğrudan ve yakından ilgilendirmektedir. Şu hâlde yoksulluğu herkes için ve kalıcı olarak ortadan kaldırabilmenin yollarından biri meseleye hak temelli yaklaşmaktan geçmektedir. Bu çalışmada yoksulluk hak ihlallerini derinleştiren sosyal bir sorun olarak ele alınırken yoksullukla mücadeleye hak temelli yaklaşım neoliberal dönüşüm sürecinde belirleyici ve işlevsel etkiye sahip olduğu düşünülen eğitim, çalışma, kalkınma ve direnme hakları özelinde değerlendirilmeye çalışılmıştır.

Anahtar kelimeler: Yoksulluk, İnsan hakları, Hak temelli yaklaşım.

\section{Giriş}

Yoksulluk, insan varlığını ve yaşamını etkileyen sosyoekonomik bir durumdur ve insanın iyilik halinin ve refahının her alanda gözetilmesini, korunmasını ve sürdürülebilir kılınmasını amaç edinen sosyal devletlerin mücadele ettiği temel bir sorunsaldır. Çok katmanlı etkileri ile yoksulluk, insani ve toplumsal gelişimin sağlanması önünde ciddi bir engeldir. Bireyleri ihtiyaç sahibi kılan koşulların bir ürünü olarak yoksulluk, yalnızca yoksulu değil, onu çevreleyen toplumu da derinden etkileyen döngüsel bir neden-sonuç ilişkisinin tümü olarak karşımıza çıkar. Mesele yalnızca yeterince beslenemediği, sağlık sorunları yaşadığı ya da iyi bir eğitim alamadığı için temel insani gereksinimlerini karşılayabilecek geliri elde etme imkânına sahip olamamakla sınırlı değildir. Yoksulluk toplumsal yaşamda havada asılı duran bir risktir ve tüketim döngüsünde süren yaşam pratiğinde işsiz kalmak, borç ödeme gücünü kaybetmek ya da iflas etmek gibi sebeplerle bu riskle her an karşı karşıya kalınabil-

\footnotetext{
* Dr., Türkiye İnsan Hakları ve Eşitlik Kurumu.

** Prof. Dr., Hacettepe Üniversitesi, İİBF, Sosyal Hizmet Bölümü.
} 
mektedir. Sosyal yardım gibi uygulamalar ise hak temelli bir yaklaşımla inşa edilmediği sürece insanları yoksulluğun yıkıcı etkilerinden ancak ve günübirlik koruyabilmektedir.

Şu hâlde yoksulluk, hak ihlallerinin hem nedeni hem de sonucu olarak kendini yeniden ve yeniden üretirken, bu zincir kırılamadığında nesilden nesile aktarılarak toplumsal yaşamdaki varlığını sürdürmektedir. Çocuklar, engelliler, yaşlılar, kimsesizler ve diğer korunması gereken gruplar açısından daha yıkıcı etkileri olan yoksulluğa karşı temel insan haklarını koruyabilmek, yoksulluk döngüsünü kırabilmekle mümkün bulunmaktadır.

Neoliberal dönüşüm ile sosyal ve ekonomik adaletsizliklerin insanları piyasadaki alım gücüne göre kategorilere ayırdığ tüketim toplumunda, yoksunluk ve yalıtılmışlık bir yaşam şeklini almaktadır. Gelinen bu nokta, yoksulluğa neden ihtiyaç temelli değil de hak temelli yaklaşılması gerektiği üzerinde yeniden düşünmeyi gerektirmektedir. Kuşkusuz insanların hakkı olan edim ve edinimlere, ihtiyacı da bulunmaktadır. Ancak insanın esasen hakkı olan "ihtiyaçlarına” yalnızca diğer kişi, kurum ve kuruluşların takdir ettiği koşul ve miktarlarda erişebiliyor olması hak ve özgürlükler açısından sorunlu bir durumdur. İnsan ile ihtiyaç duyduğu mal ve hizmete erişimi arasındaki mesafe de giderek derinleşmektedir. Bu derinliği yorumlama şeklimiz yoksullukla mücadelemizin de sonucunu belirleyecektir.

Yoksulluğun mutlak gerçeklik olarak kabul edilip yönetilebilir bir sosyal sorun olarak kanıksanması, insan haklarının klientalist ilişkilerin, nepotizmin ve lütuf kültürünün gölgesinde kalacağının ve söylemden eyleme dönüşemeyeceğinin işaretleri olarak kabul edilebilir. Söyleme indirgenen insan hakları anlayışı ile eşitsizlikler kalıc1 hale gelir ve "hak" bir “ideal” olarak algılanır. Kuşkusuz eğer insan hakları, koruma gerektiren birkaç temel değeri akla getiriyorsa, her insan için her şeyi ifade edebilecek bir kavram olamaz. ${ }^{1} \mathrm{Bu}$ nedenle yoksulluğu, insan hakları ve eşitlik yaklaşımı içinde ve gerçekçi şekilde değerlendirebilmek oldukça kritiktir. Yaklaşımın başlangıç noktasını ise yoksul insanları 'ihtiyaç sahipleri' olarak değil; hak sahibi bireyler olarak kabul etmek oluşturur. Bu yaklaşımı geliştirmek için ise siyasi, sosyal, kültürel ve ekonomik politikaların odağına, sahip olduğu hakları kullanan ve yaşayan insanı yerleştirmek gerekir. Aksi halde “insan ve hak" yasa, sözleşme vb. metinlerde yan yana gelen ve fakat fiili yaşamda yoksulluk gibi derin uçurumları içinde barındıran iki ayrıksı gerçeklik olarak var olmaya devam edecektir.

Bu çalışmada yoksulluk bir insan hakları ihlali olarak ele alınmaktadır. Bu bağlamda, günümüz üretim ve bölüşüm ilişkileri temelinde, insanların özbelirlenim haklarını kullanabilmelerinin temel bir yolu olarak çalışma, eğitim, kalkınma ve direnme haklarının yoksullukla mücadelede belirleyici gücüne değinilecektir.

\section{Bir İnsan Hakları İhlali Olarak Yoksulluk}

İnsan haklarının çıkış noktasında, insan hak ve özgürlüklerinin ihlallere ve ihlal

1 Samuel Moyn, Son Ütopya: Tarihte İnsan Hakları, çev. Firdevs Ev, İstanbul: Koç Üniversitesi Yayınları, 2016, s.193. 
edebilecek kişi ve aktörlere karşı korunması ve güvence altına alınması anlayışı yatmaktadır. Bireyin hak ve özgürlüklerinin güvenceye alınması ancak özgür ve demokratik bir toplumda olanaklıdır. ${ }^{2}$ Ancak özgür, adil, demokratik ve şeffaf bir toplumda insanlar, haklarını yaşama ve kullanma olanaklarına sahip olabilirler. $\mathrm{Bu}$ nedenledir ki çetin mücadelelere sahne olan insanlık tarihi, aynı zamanda hak, eşitlik, adalet ve özgürlük arayışının da tarihidir.

$\mathrm{Bu}$ arayış, insanın yaşadığı topluma, o toplumda yaşayan herkesle eşit bir birey olarak katılımı önündeki engeller ortadan kalkıncaya dek sürecektir. Çünkü bugün insanlık yarattığ 1 değerler ile yaşadığı yoksulluğu hak etmemektedir. ${ }^{3} \mathrm{Bu}$ anlamda yoksulluk, önemli sayıda insanın yaşamını ve yaşam kalitesini etkileyen, hak ihlalleri yaratan ve eşitsizlikler bağlamında önemli sayıda neden ve sonuç ilişkisi barındıran çok boyutlu bir sorun olarak varlığını sürdürmektedir.

Yoksulluğun nedenlerine yönelik yaklaşımlar; yoksulluğu, kişilerin yetenekleri, sorumluluk ve disiplin anlayışı, tutumluluk derecesi ve gösterdikleri çaba gibi kendi kişisel özellikleriyle ilişkilendiren ve yoksulları yoksulluğun hem kurbanı hem de nedeni olarak gören yaklaşımla; başta ekonomi politikaları olmak üzere, düşük ücretler, yetersiz eğitim ve istihdam olanakları ile ayrımcılık gibi yoksulların kendi denetimleri dışındaki yapısal etmenlerle ve bütünüyle sosyoekonomik sistemle ilişkilendiren yaklaşım itibariyle iki başlık altında değerlendirilebilir. ${ }^{4}$ Yoksulluğa yol açan nedenlerden biri olarak ayrımcılık özellikle servet, engellilik, cinsiyet, yaş, rrk ve bölgesel farklılıklar temelinde hizmetlere eşit koşullarda erişimi engellemekte, yol açtığı sosyal dişlanma sebebiyle yoksulluğun bir kısır döngüye dönüşerek süreğenleşmesine neden olmaktadır.

Genel olarak alan yazında birbiriyle ilişkili üç ayrı yoksulluk tanımının varlığından söz etmek olanaklıdır. Bunlardan ilki, temel yiyecek gereksinimlerini karşılamak için gerekli gelirden yoksunluk olarak tanımlanan mutlak yoksulluk; ikincisi, yiyecek gereksiniminin yanı sıra giyim, barınma vb. gereksinimlerin de karşılanabilmesi için gerekli olan gelirden yoksunluk olarak göreli yoksulluk iken üçüncüsü okuryazarlık, yetersiz beslenme, kısa yaşam süresi, ana-çocuk sağlığının yetersizliği, önlenebilir hastalıklara yakalanmak gibi insani olanaklardan yoksunluk olarak açıklanan insani yoksulluktur. Yoksulluğu açıklamak için bu kavramların yanı sıra gelir yoksulluğu, çalışan yoksulluğu, kadın yoksulluğu, çocuk yoksulluğu, yaşlı yoksulluğu, nesnel yoksulluk, öznel yoksulluk, kırsal-kentsel yoksulluk gibi yoksulluğun yaşandığ 1 mekânlar ve etkilediği kesimler özelinde geliştirilen bir alan yazın da bulunmaktadır.

İnsani yoksulluk kavramını geliştiren Amartya Sen "Kapasite Yaklaşımı”nda, gelirin nihai kapasite üzerindeki etkisini koşullu ve kısmî olarak ele alır ve bireylerin yoksulluk düzeylerini araç durumunda olan gelirden çok, amaç durumunda olan bire-

2 Kasım Karataş, Yoksulluğun Küreselleşmesi ve Yoksulluğa Karşı Küresel Tavır: Değişen Türkiye’de İnsan Hakları Açısından Sosyal Hizmetler, der. Kasım Karataş, Ankara: Sosyal Hizmet Uzmanları Derneği Yayını, 2002, s.153. 3 Beril Tufan ve Kasım Karataş, "Yoksulluk ve Sosyal Hizmetler", (Sosyal Hizmet Sempozyumunda Sunulan Bildiriler, Hacettepe Üniversitesi ve Akdeniz Üniversitesi, Antalya, Ekim 2003), s.15.

4 Fikret Şenses, Küreselleşmenin Öteki Yüzü: Yoksulluk Kavramlar, Nedenler, Politikalar ve Temel Eğilimler, İstanbul: İletişim Yayınları, 2009, s.145-146. 
yin yapabilme kapasitesi temelinde değerlendirir. Yaşlılık ve engellilik gibi durumlar, hem bireyin gelir edinme kapasitesini azaltır, hem de elde edilen gelirin işlevlere dönüştürülmesindeki verimi düşürür. ${ }^{5}$ Dolayısı ile bireyin yoksulluğu, bütün olgulardan soyutlanmış bir araç olarak gelir tarafından değil, gelirin de içinde olduğu toplumsal cinsiyet, üretim araçları mülkiyetinin dağılımı ve bireysel dezavantajlar gibi çok sayıda etmen tarafından belirlenen toplumsal piramit içindeki konumlanma ile açıklanmalıdır. ${ }^{6}$ Bu nedenle Sen’e göre açlık ile önlenebilir hastalık ve ölümden korunma, toplumsal yaşamda yer bulabilme ve toplum için şerefli bir konumda bulunma olanaklarına yeterli düzeyde sahip olamamak; yoksulluktur. Bu çerçevede yoksul oluşu ve sınırlarını belirleyen dışsal değişkenleri, yoksul insanların neye sahip oldukları ile değil, sahip oldukları ile neler yapabildiklerinin şekillendirdiği söylenebilir.

Sefalet, açlık, yokluk, yoksunluk ya da muhtaçlık gibi kavramlarla da ilişkilendirilen yoksulluk, pratik yaşamda yetersiz gelir, beslenme, eğitim, sağllk ve çevre koşulları ile karakterize edilmektedir. Yarattı̆̆ döngüsel nedensellik ilişkisi içerisinde tüm bu gayriinsani koşullar, aynı zamanda birer hak ihlalidir. Bu hak ihlallerinin çoğunlukla hem nedeni hem de bir sonucu olarak sosyal dışlanma ve yabancılaşma gibi sorunları da barındırması, hangi yoksulun hangi haklarından daha yoksun yaşamlar sürdüğü sorusunu gündeme getirmektedir. Bu çok katmanlı sorunsalı hak temelli yaklaşım açısından değerlendirebilmek için başlangıç noktamızı, hangi coğrafyada ve hangi koşullar altında yaşıyor olursa olsun, her insanın özgür ve onurlu yaşamlar sürecek olanaklara fırsat eşitliği içerisinde ve sosyal adalete dayalı olarak erişmesini mümkün kılacak bir anlayış oluşturmalıdır. Yoksulluğu, yaşam hakkının yanı sıra insanca yaşamayı olanaklı kılan bütün insan haklarının dilinden konuşabilmek için insan yaşamında yarattığı maddi ve manevi yıkıcı etkisini görebilmek gerekmektedir.

$\mathrm{Bu}$ etki özellikle küresel eşitsizliklerden bahsettiğimiz dünyamız için esasen yepyeni bir olgu değildir. Kapitalizm, sömürgecilik ve bunların sonucunda ortaya çıkan yozlaşma ve baskı, oldukça tanıdıktır ve küresel ekonominin yeni eserleri oldukları söylenemez. ${ }^{7}$

Bu bağlamda yoksulluk refahın adil dağlımına dair kadim bir meseledir ve kalkınmadan alınan payın eşitlenememe hali olarak varlığını sürdürmektedir. Paydayı oluşturanlar ile pay sahipleri arasındaki orantısız ilişki doğası gereği eşit değildir ve çelişkilerle doludur. ${ }^{8}$ Öyle ki obezite nedeniyle ölen insanlar ile açlıktan ölen insanları geride bırakmış durumdadır. Aşırı tokluğun açlıktan daha ölümcül bir sorun olarak insan yaşamını tehdit ettiği dünyamızda, yaşam hakkının olmazsa olmaz unsurlarını oluşturan temiz su, gıda, çevre ve sağlık gibi temel haklara erişimde güçlük yaşayan milyonlarca insanın olması da ayrı bir çelişkidir.

İnsanların temiz suya, gıdaya, çevreye ve sağlıklı olmaya yaşamlarını kuşkusuz

5 Amartya Sen, Özgürlükle Kalkınma, çev. Yavuz Alogan, İstanbul: Ayrıntı Yayınları, 2004, s. 128.

6 Sen, Özgürlükle Kalkınma, s.131.

7 Jim Ife, İnsan Hakları ve Sosyal Hizmet, çev. S. Erdem Türközü ve Aslıhan Aykara, Ankara: Nika Yayınevi, 2017, s.37.

8 Coşkun Can Aktan, Yoksullukla Mücadele Stratejileri, Ankara: Hak-İş Konfederasyonu Yayınları, 2002, s.iii. 
ihtiyaçları da bulunmaktadır. Bu noktada ihtiyaç olgusunu ele almamızda yarar bulunmaktadır. Bir ihtiyacı yaşamsal, sürekli ve şiddetli kılan faktörler ihtiyacı doğuran nedenlere, karşılanma sıklığına ve düzeyine göre değişebilmektedir. Bradshaw ihtiyaçları şu şekilde sınıflandırmaktadır:

"Normatif İhtiyaç: Toplumda geçerli olan bir norma göre tanımlanmış ihtiyaçlardır. Bu normlar genellikle uzmanlarca...belirli ölçütlere göre saptanır...Kıyaslamalı İhtiyaç: İhtiyaç sahipleri ile olmayanlar arasında kıyaslama yapılarak ortaya çıkarılan ihtiyaçtır. Sosyal sorunların hangi alanlarda daha yoğun yaşandığını tespit ederek ihtiyaçları açı̆̆a çıkarmak amaçlanır...Hissedilen İhtiyaç: İhtiyaç sahibi olan kişinin kendisinin hissettiği ihtiyaçtır...İfade edilen İhtiyaç: Bireylerin var olduğunu beyan ettikleri ihtiyaçtır. Bireyler ifade edemedikleri bir ihtiyacı hissedebilirler ve hissetmedikleri ihtiyacı beyan edebilirler." 9

Yoksulluk genel olarak normatif ihtiyaçları karşılama olanağı sunan gelir düzeyi temel alınarak belirlenmektedir. Yoksulluk ölçümünde temel alınan bu düzey, insanların yaşamlarını idame ettirebilmeleri için gerekli ihtiyaçların piyasa değeri üzerinden hesaplanmakta ve genellikle açlık sınırı, yoksulluk sınırı veya geçim maliyeti gibi kavramlarla ifade edilmektedir. Ancak elbette ihtiyaçlar mali ederi ile sınırlı değildir ve hak bağlamından ayrıksı bir gerçekliği ifade etmemektedir. Doğası gereği her ihtiyaç bir değer yüklüdür ve farklı değerlerin, belli bir durumda neye 'ihtiyaç duyulduğuna' dair de farklı görüşleri olacaktır. ${ }^{10}$ Hak temelli yaklaşım tüm insanlar için evrensel ve bölünmez bir bütün olarak ve esasen bir ihtiyacın karşılanmasını da içerecek şekilde insan haklarını referans alır. Ancak burada kişisel ve kültürel farklılıklara dayalı olarak ihtiyaçların göreli olarak değişebileceğini dikkate almak ve hak temelli yaklaşımı farklı toplumsal, kültürel vb. bağlamlar çerçevesinde yorumlayabilmek gerekmektedir.

Bu nokta iç içe geçmiş iki olgu olarak hakların gerçekleşmesinde / ihtiyaçların karş1lanmasında sorumlulukların nasıl ve neye göre tanımlandığını anlayabilmek açısından önemlidir. Tanımlanan sorumlulukların özellikle yoksul bireyleri ihtiyaç sahibi olarak etiketleyen ve güçsüzleştiren bir değer alanı mı ortaya koyduğu; yoksa onları hak sahibi bireyler olarak tanımlayan güçlendirici bir işlevi mi ortaya koyduğu, yoksullukla mücadelede keskin bir yol ve yöntem ayrımı oluşturmaktadır. İnsanı bireysel olarak yoksullukla mücadelesinde etken ve edilgen kılan koşulların şekillenişi de esasen yoksul insanların hak sahibi bireyler olarak kabul edilip edilmediği ile belirlenmektedir.

İnsanı yoksullukla ilişkisinde yalnızca ihtiyaç sahibi olarak gören anlayış ve bu anlayışın hak ihlallerine zemin oluşturan doğası karakteristik özelliklerini koruma eğilimindedir. Bununla birlikte sosyal devlet ve hukukun üstünlüğü ilkeleri temelinde insanlık eşitlik, sosyal adalet ve hak mücadelesini sürdürmeye devam etmektedir.

9 Jonathan Bradshaw, The Taxonomy of Social Need, Jonathan Bradshaw on Social Policy, ed. Richard Cookson, Roy Sainsbury, Caroline Gelndinning, University of York, 2013, s.1-3.

10 Ife, İnsan Hakları ve Sosyal Hizmet, s.114. 
Sahlins'in ${ }^{11}$ ifade ettiği gibi yoksulluk; "mal-mülk miktarının belirli düzeyin altında olması değildir; sadece amaçlar ve araçlar arasındaki bir ilişki de değildir; yoksulluk her şeyden önce insanlar arasındaki bir ilişkidir: sosyal bir konumdur." Yoksullukla mücadelede bu "sosyal konumlanmanın" insan hakları perspektifine sahip politika, karar ve uygulamalar ile geliştirilmesi kuşkusuz mümkündür. Yoksulluk dün olduğu gibi bugün de nedenleri ve etkileri öngörülebilen bir sorundur. Ancak bugün dünden daha fazla dikkat edilmesi gereken husus, yoksulluğa karşı insan haklarının korunması ve hak temelli yaklaşımın savunulmasıdır.

\section{Yoksulluğa Karşı İnsan Hakları}

Yoksul olmamak ve yoksunluklarla örülü yaşamlar sürmemek bir haktır. Ancak bu hakkın gerçek yaşamda karşılık bulabilmesi, başta çalışma, eğitim, kalkınma ve direnme hakkı olmak üzere belirleyici ve işlevsel öneme sahip olduğunu bildiğimiz bazı hakların herhangi bir ayrımcılığa uğramadan kullanılması ve insani gelişimin adil bir şekilde desteklenmesi ile olanaklıdır.

İnsanları haklarını kullanmaktan doğrudan ya da dolaylı olarak yoksun bırakan koşulların ortadan kaldırılması için ulusal ve uluslararası aktörlere yükümlülükler tanımlanmıştır. Bu yükümlülüklerin temel çerçevesini İnsan Hakları Evrensel Beyannamesi'nin (İHEB) 17, 22, 23, 25 ve 26. maddelerini referans alarak açılayabiliriz:

"Herkesin tek başına veya başkalarıyla ortaklaşa mülkiyet hakkı vardır... Herkes ... sosyal güvenlik hakkına sahiptir ve haysiyeti ve kişiliğini özgürce geliştirebilmek için ekonomik, sosyal ve kültürel haklarını... gerçekleştirebilir... Herkesin çalışma hakkı vardır... Herkesin; gıda, giysi, barınma, sağlık bakımı ve gerekli sosyal hizmetler de dâhil olmak üzere, kendisinin ve ailesinin sağlık ve esenliği için gerekli olan yaşam standartlarına hakkı vardır... Herkesin eğitim hakkı vardır ..."

Her insanın yoksulluk tehdidinden uzak bir yaşam sürmek ve bunu sürdürülebilir kılmak için yukarıda sıralanan hak ve yaşam standartlarına ihtiyacı olduğu gibi hakkı da vardır. Ki insan haysiyeti, mevcut haliyle çok sayıda farklı olguyu içinde toplayan boş bir aracıdan, sınıflandırıcı bir ifadeden ibaret değildir; aksine tüm temel hakların beslendiği ahlaki bir kaynaktır. ${ }^{12}$ Ancak bu hakların kullanılması çoğu durumda eşitsizliklerin aşılmasına ve fırsat eşitliğine bağlıdır. Fiili eşitliğe ve kaynakların adil dağılımına dayanan bir sosyal, ekonomik ve politik düzende, her insanın onurlu bir yaşam sürdürebilmesi ise hukukun üstünlüğü, adil yargılanma hakkı, ayrımcılık yasağ 1 ile olanaklıdır. ${ }^{13}$

Bu hak ve özgürlükler birbirini tamamlayan ve mümkün kılan nedensel bir bütün-

11 Marshall Sahlins, "Taş Devri Ekonomisi” (2010) adlı kitabında ilkel toplumların eşitlikçi yapılarını nasıl koruduğunu incelemiş, okuyucuyu refah ve devlet olguları üzerinde yeniden düşünmeye zorlayan, hane tipi üretim tarzına dayalı bir model geliştirmiştir.

12 Jürgen Habermas, "The Concept of Human Dignity and the Realistic Utopia of Human Rights", Metaphilosphy, 41/IV (2010), s.470.

13 Ayrıntılı bilgi için bakınız. İHEB Md. 1, Md. 2, Md. 7, Md. 8, Md. 9, Md. 10 ve Md. 11. 
lüğe sahiptir. Karataş' $ı n^{14}$ belirttiği gibi, insan hakları uluslararası belgelerde, devletlerin anayasalarında, diğer hukuksal düzenlemelerde, uygulamalarda ve en sonunda bireysel bilinçlerde varlık bulan dinamik bir kavramdır ve gerçekleşmesi; toplumsal kalkınmanın sağlanmasına ve bu ise etkin bir sosyal refah örgütlenmesinin oluşumuna bağlıdır. Sadece haklara vurgu yapmaktan öteye neden geçmemiz gerektiğini açılayan bir diğer sebep de insani boyutun ihmal edilmesi, kültürel farklılıkların bir kenara atılması ve bağlamsal koşullanmaların kabul edilmemesidir. ${ }^{15}$ Kuşkusuz insan ve hakları bir bütündür ve yoksulluğa karşı verilen mücadelede de sorunun insani, kültürel vb. koşullanmalarla yakından ilgisi vardır.

Diğer taraftan insanların sahip olduğu hakları diğerinden daha önemsiz ya da daha üstün ele almak hak temelli yaklaşım ile bağdaşan bir anlayış değildir. ${ }^{16}$ Örneğin sağlık hakkı, her insanın yaşamı için en temel haklardan biridir ve BM Ekonomik ve Sosyal Konseyi 11 Ağustos 2000 tarihli "Olanaklı Olan En Yüksek Sağlık Standardına Sahip Olma Hakkına” ilişkin genel yorumunda şu ifadeye yer vermektedir:

"Sağlık hakkı, diğer insan haklarının kullanımı için vazgeçilmez olan temel bir insan hakkıdır. İnsanlık ailesinin bütün üyelerinin, insanlık onuruna yaraşır bir yaşam yaşamaya vesile olacak, olanaklı olan en yüksek seviyedeki sağlık standartlarına sahip olma hakkı vardır."

Ancak günümüzde sağlık standardı da insanların ekonomik gelirine göre farklılaşabilmektedir. Tanımlanmış bir sağlık sisteminde eşit haklara sahip bireyler, elde ettikleri gelire bağlı olarak farklı standartlarda sağlık hizmeti alabilmektedir. Ancak düşük nitelikteki hizmetlere erişebilen yoksulların yaşadıkları hak ihlallerinin hukuk sistemi içerisinde nasıl tanımlandığı ve sosyal hakların hangi yasal güvenceler çerçevesinde koruma altına alındığı önem taşımaktadır. Sağlık, eğitim ve diğer temel hizmetlerden etkin şekilde faydalanamamak, ortalama bir gelir düzeyine sahip olamamak sadece yoksulluğa değil var olan hakları kullanmaktan yoksunluğa da işaret etmektedir. Makalemizin sınırları içerisinde insan onuruna yaraşır yaşamları olanaklı kılan bu haklardan yalnızca çalışma, eğitim, kalkınma ve direnme haklarına yer verilecek olması, gelir dağılımındaki eşitsizliklerin ve gelir yoksulluğunun ele aldığımız sorunsal üzerinde artan belirleyici etkisi ve bu etkiyi bertaraf edebilecek tedbirlerin işlevsel önemi ile açıklanabilir.

\section{Çalışma Hakkı}

Yoksulluk toplumsal temelde üretim ve bölüşüm ilişkilerindeki eşitsizliklerin bir sonucudur ve gelirin adil dağılımı ile yakından ilişkilidir. Çalışmak ise insanın kendisini ifade edebilmesinin ve toplumun saygın bir üyesi olabilmenin temel yollarından birisidir. Yetersiz ekonomik büyümeye veya üretimde insanın yerini teknolojinin alma-

14 Karataş, Yoksulluğun Küreselleşmesi ve Yoksulluğa Karşı Küresel Tavır, s.150-156.

15 Amos Nascimento, İnsan Hakları ve Kozmopolitik Paradigmaları: Haklardan İnsanlığa, der., Matthias LutzBachmann, Amos Nascimento, İstanbul: Koç Üniversitesi Yayınları, 2016, s.128.

16 Bütün insan haklarının karşılıklı bağımlılığı ve bölünmez bütünlüğü 1968'de BM bünyesinde kabul edilen ve kişi özgürlükleri ile siyasal haklar hakları, ekonomik ve kültürel haklara bağlayan Tahran Bildirisinin yanı sıra 1993 yılında kabul edilen Viyana Bildirisi’nde de vurgulanmıştır. 
sına eşlik eden işsizlik ve beraberinde getirdiği yoksulluk, ekonomik hakları ön plana çıkarmıştır. Gelir dağılımındaki eşitsizliklerin yanı sıra gerçek ücretlerin artmaması, ücret eşitsizliklerinin korunması, büyümenin istihdam yaratmaması sınırlı mali güce sahip insanlar üzerinde bu yükün daha da ağır hissedilmesine yol açmaktadır.

İstihdam üzerinde baskı oluşturan temel göstergelerden bir diğeri ise nüfustur. Nüfus artışının yanı sıra emek sektörünün daralması insanların istihdam olanaklarına erişimini ve dolayısıyla refah düzeyini önemli ölçüde etkilemektedir. Hızlı nüfus artışı özellikle azgelişmiş ülkelerde önemli bir yoksulluk nedeni olarak ortaya çıkarken, gelişen üretim teknolojisi ile birlikte işgücü maliyetlerini bir rekabet unsuru olarak aşağıya çeken ekonomiler istihdam alanlarını daraltıcı etkide bulunmaktadır.

Demografik unsurların yanı sıra göç olgusu da işsizliğin ve yoksulluğun nedenleri arasında sıralanmaktadır. Yoksulluk, işsizlik ve göç arasında karmaşık bir ilişki vardır. Bir görüşe göre, hızlı kentleşmeyle beraber, kentsel yoksulluk, kırsal yoksulluğun bir yansıması olarak görülmekteyken, diğer bir görüşe göre yoksulluk göçü özendirmek bir yana, kısıtlayan bir etmen olarak ortaya çıkmaktadır. ${ }^{17}$ Ancak özellikle kitlesel göçle gelen insanların ucuz işgücü olarak yeni ülke ekonomisine eklemlenmesi, hali hazırda istihdam edilenlerin işsiz kalmalarına veya iş güvencelerini kaybetmelerine yol açabilmektedir. Diğer yandan Şenses'in ${ }^{18}$ belirttiği gibi, göçün, göç eden yoksul bireylerin ve bunların çıtığı ve göç sonunda yerleştiği yerleşim yerinin yoksulluk düzeylerini ne yönde etkileyeceğini önceden kestirmek zordur.

Burada önemli olan husus göçmen olsun ya da olmasın bir ülkede yaşayan her bireyin istihdam hakkını insana yakışır iş olanakları çerçevesinde kullanabilmesidir. Özellikle kayıt dışı istihdam edilen, düşük ücretlerle çalıştırılan ve sosyal güvenlik hakkından mahrum bırakılan insanlar için istihdamda olmak, yoksulluk eşiğini aşabilme imkânı sağlamamaktadır. Adaman ve Keyder ${ }^{19}$ kayıt dışı istihdamı, yoksulluğun en önemli nedenlerinden biri olarak değerlendirdikleri çalışmalarında gecekondu ve çöküntü mahallelerinde yaşanan yoksulluğun nedenlerini "yüksek işsizlik, enformel yapı ile formel yapının iç-içe bulunması, mevsimsel emek taleplerinde yaşanan dalgalanmalar, kadınların emek piyasasına katılım oranlarının düşüklügü, çocuk emeğinin yüksek oranda kullanımı, sendikal haklarda yaşanan erozyon, gelir ve servet dağılımında yaşanan eşitsizlikler, bölgesel gelişim farkları” olarak sıralamışlardır.

Diğer taraftan hane geliri ile fert sayısı arasındaki ters orantı, hanedeki bireylerin iyi bir eğitim alarak tam istihdam hakkını kullanabilmesi önünde bir engel oluşturabilmektedir. Yoksulluğun boyutları ve büyüklüğü çeşitlense bile bireysel ve ailesel düzeyde yoksulluğun nedenleri yüzyıllar boyu bir süreklilik göstermiştir. Bugün bile, geçmiş yüzyıllarda olduğu gibi, yoksul diye adlandırılanların çoğunu on beş yaş altındaki çocuklar, yaşlılar ve reisliğini kadınların yaptığ haneler oluşturmaktadır. ${ }^{20}$

17 Şenses, Küreselleşmenin Öteki Yüzü, s.161-162.

18 Şenses, Küreselleşmenin Öteki Yüzü, s.162.

19 Fikret Adaman ve Çağlar Keyder, “Türkiyede Büyük Kentlerin, Gecekondu ve Çöküntü Mahallelerinde Yaşanan Yoksulluk ve Sosyal Dışlanma, Avrupa Komisyonu Çalışma”, (Sosyal İşler ve Fırsat Eşitliği Dairesi Araştırma Raporu, VC/2005/0155), İstanbul, 2006, s.125.

20 Robert Jütte, Erken Modern Avrupa'da Yoksulluk ve Sapkınlık, çev., Bengü Kurtege Sefer, İstanbul: Boğaziçi 
Üretim ilişkilerinde ve aile yapısındaki değişim özellikle hanede çocuklar, yaşlılar ve hastalar açısından bakım hizmetine olan gereksinimi arttırırken, bu gereksinimi piyasadan satın almak durumunda olanların elde ettikleri gelir düzeyi, bakım için göze alınabilecek maliyetin gerisinde kaldığında istihdamda olmak anlamını yitirebilmektedir. Bu bağlamda aile ve bakım sigortalarının yokluğu, çalışma hakkını dolaylı olarak etkileyen bir diğer neden olarak kabul edilebilir.

İstihdam hakkının insana yakışır işler bağlamında kullanılamaması, kayıt dışı istihdamın, düşük ücretlerin, güvencesiz işlerin ve iş sağlığ 1 ve güvenliği risklerinin hâkim olduğu bir işgücü piyasası anlamına gelir ki bu durum da insanları yoksullaştıran bir diğer hak ihlalidir. İnsan onur ve haysiyetine yakışır koşullarda her insanın amaç ve ideallerini firsat eşitliği içerisinde gerçekleştirebileceği istihdam olanaklarına sahip olabilmek, yoksulluk tehdidi altında gayriinsani koşullarda çalışmaya razı olmak zorunda kalan her insanın hakkıdır. Diğer taraftan yapısal özellikleri ile doğru orantılı olarak işsizlik, işsiz insanların eğitim, sağlık, barınma gibi temel haklarını kullanmalarını da etkileyen temel bir sosyoekonomik sorundur. İşsizlik sigortasının yeterince kurumsallaşamadığı ve yeni iş alanlarının desteklenmediği ülkelerde bu sigorta kolundan sağlanan işsizlik ödeneğinin etkisi geçici bir süre ile sınırlı kalmaktadir.

Bu bağlamda yoksulluk olgusu toplumsal bütünleşme ihtimalini büyük çapta ortadan kaldıran koşulların bir ürünüdür. Bu konumda olan insanlar köylülükten yahut küçük üreticilikten veya kayıt dışılıktan kent ekonomilerinin daha bütüncül bir parçası olmaya geçişi bütünüyle tamamlayamamaktadır. Sürekliliği olmayan işlerden elde ettikleri gelir bir birikim oluşturmaz; hatta olması gereken ölçüde ailenin yeniden üretimini (çocukların gereği gibi beslenmesi ve eğitimini) karşılayamaz. ${ }^{21}$

\section{Eğitim Hakkı}

Eğitim hakkı yoksulluk gibi toplumsal sorunların yaşanmaması ya da önlenebilmesi için sosyal adaletin yapı taşı niteliğinde olan bir haktır. Bu hakkın ihlali geçmişte meşru bir temele dayandırılmış ve eğitim yalnızca "seçkin" insanların alabileceği bir hizmet olarak kabul edilmiştir. Bu meşru temelin terminolojisi alan yazında alt sınıf, sınıf altı ya da dip sınıf şeklinde karşımıza çıkmaktadır. Yoksul bireylerin yaşam algılarını sorumsuzluk ve tembellik ile sınırlandırılan bu yaklaşım yoksulları, sosyal refah devletini ve vergi ödeyenleri haksız yere sömürmekle itham eder ve bunu ortaya çıkaran nedenleri, alan yazındaki kuramlar çerçevesinde, üçe ayırır: bireysel, kültürel ve yapisal nedenler.

Ancak sorulması gereken soru Kelso'nun²2 ifadesiyle şudur: "Yoksullar bireysel olarak hazırlıksız ya da eğitim bakımından yetersiz oldukları için mi; motive olmadıkları ya da olamadıkları için mi; yoksa iyi maaşlı işler bulamadıkları için mi yoksuldur-

Üniversitesi Yayınevi, 2011, s.228.

21 Ayşe Buğra ve Çağlar Keyder, Yeni Yoksulluk ve Türkiye’nin Değişen Refah Rejimi, (Birleşmiş Milletler Kalkınma Programı İçin Hazırlanan Proje Raporu), İstanbul, 2003, s.24.

22 Alev Erkilet, "Sınıf-Altı: Kuramsal Tartışmalar ve İstanbul Tarihi Yarımada’ya Uygulanma İmkânları", Marmara Üniversitesi Sosyal Bilimler Enstitüsü Öneri Dergisi, 9/ 36 (2011), s.137-146. 
lar?" 'Hak etmeyen' yoksulların ahlaki değerlerden yoksun (örneğin çalar, hile yapar, cinsel ahlakları düşüktür), tembel ve kaytarıcı olduklarına, eğitilmeyi ve kendilerini geliştirmeyi istemeyen kişiler olduklarına dair inanç, orta çağın son döneminde ortaya çıkmıştır. ${ }^{23}$ Örneğin İngilterede 1834 tarihli "Yeni Yoksul Yasası" (Poor Law) ile yoksul tanımı "iş göremez (mülksüz)" olarak sınırlandırılmıştır.

Bugün, nispeten, yoksul insanlara yönelik bu gibi güçlü önyargıların kırıldığı bir dünyada yaşıyoruz. Bunun önemli nedenlerinden birisi de hiç kuşkusuz, eğitim hakkını kullanarak olguların nedenlerini ve sonuçlarını irdeleyebilen insanlar olmuştur. Bugün pek çok ülkede eğitim anayasal bir haktır ve ulusal bir kamu bir hizmeti olarak verilmektedir. Bu noktaya gelinmesinde Birlemiş Milletler (BM) Genel Kurulu'nun 10/12/1948 tarih ve 217 (111) sayılı kararı kabul edilen ve Türkiye'nin de tarafı olduğu İHEB etkili olmuştur ve eğitim hakkını düzenleyen 26. maddesi şu şekildedir:

"1. Herkes eğitim hakkına sahiptir. Eğitim en azından ilk ve temel safhalarda parasız olmalıdır. İlköğretim mecburidir. Teknik ve mesleki eğitim genel olarak mevcut hale getirilmeli ve yüksek öğretim yetenek temelinde herkese eşit düzeyde erişilebilir olmalıdır.

2. Eğitim insan şahsiyetinin tam gelişmesini ve insan haklarına ve temel özgürlüklere saygının kuvvetlenmesini hedef almalıdır. Eğitim bütün milletler, ırksal ve dinsel gruplar arasında anlayış, hoşgörü ve dostluğu teşvik etmeli ve Birleşmiş Milletlerin barışın idamesi yolundaki aktivitelerini daha ileri taşımalıdır.

3. Ebeveynler, kendi çocuklarına verilecek eğitim türünü seçmek hakkını öncelikle haizdirler."

Beyanname’nin 2. maddesi ile birlikte ele alındığında eğitim hakkı; ırk, renk, cinsiyet, dil, din, politik ya da başka bir görüş, ulusal ya da toplumsal köken, servet, doğuş veya diğer statüler bakımdan ayrım gözetilmeksizin herkesin sahip olduğu bir haktır.

Eğitim hakkının yalnızca insan olmaktan kaynaklanan temel bir hak olması, bu haktan herkesin yararlanması sonucunu ne yazık ki beraberinde getirmemektedir. Özellikle yoksulluk bu haktan yararlanma konusunda somut engeller barındırabilmektedir. Bu nedenledir ki yukarıda yer alan (1) numaralı paragrafta "Eğitim en azından ilk ve temel safhalarda parasız olmalıdır" ifadesine yer verilmiştir. Yine benzer bir yaklaşımla Ekonomik, Sosyal ve Kültürel Haklar Uluslararası Sözleşmesi'nin 13. maddesinin iki numaralı paragrafında ilköğretimin herkes için zorunlu ve bedelsiz olması, teknik ve mesleki eğitim de dâhil olmak üzere ortaöğretimin ve yükseköğretimin herkes tarafindan ulaşlabilir ve tedrici olarak bedelsiz hale getirilmesi ile yeterli bir burs sisteminin yerleştirilmesi hususları yer almaktadır.

Bir hakkın yalnızca düzenlemelerde yer alması değil, bununla birlikte, yaşanabilir olması; fiziksel ve ekonomik olarak ulaşılabilir olması o hakkın kullanılabilmesini sağlamaktadır. Çalışmamız özelinde eğitim hakkı, yoksulluğu nesilden nesile akta-

23 Jütte, Erken Modern Avrupa'da Yoksulluk ve Sapkınlık, s.186. 
ran döngüyü kırabilen belki de en önemli haklardan biridir. Günümüzde servet yine de bu eğitimin kalitesini ve sürekliliğini belirleyici bir etken olarak karşımıza çıkabilmektedir. Bu durumda yoksulluk eğitim hakkından etkili bir şekilde yararlanmanın önünde bir engel oluşturabilmektedir.

Diğer taraftan bugün dünyanın en başarılı eğitim sistemi olarak öne çıkan Finlandiya’da zengine ve fakire eşit fırsat ilkesinin öne çıktığı görülmektedir. ${ }^{24}$ Finlandiya’nın kaliteli kamu eğitimini sadece eğitim değil aynı zamanda sosyal politikaların bir sonucu olarak da gören anlayışı, reforma imza atan eğitimcilerden Pasi Sahlberg 'Finlandiya Dersleri” kitabında şu ifadeler ile özetliyor: "Yüksek sosyal refah düzeyi, çocuklar için eşit fırsatlar, aynı zamanda bedava ve kaliteli öğrenmeyi garantilemekte kritik bir rol oynuyor... Sosyal eşitsizlik, çocuk yoksulluğu ve temel hizmetlerin yetersizliği bir ülkenin eğitim sisteminin performansını azaltan güçlü bir etkeni oluşturuyor."

Eğitim hakkının yalnızca yoksul bireyler açısından değil toplumun tümü için de yüksek kamu yararı barındıran bir hak olduğunu göz önünde bulundurarak herkes tarafından en kaliteli, verimli ve etkili şekilde kullanılmak üzere hak sahiplerine sunmak, yoksullukla mücadelenin de en etkili yollarından biri olarak karşımıza çıkmaktadır. Nitekim eğitim düzeyi arttıkça insanların istihdama katılım ve gelir düzeylerinin yanı sıra insan hakları bilinci de yükselmektedir. Bu anlamda eğitim, her insanın insanca yaşama hakkına sahip olduğu bilgisini özümsemiş ve yaşam pratiğine aktarmış insanlardan oluşan bir topluma giden yolun kilit unsurlarından biri olarak kabul edilebilir.

\section{Kalkınma Hakkı}

Yoksulluğu dünyanın sunduğu fırsatlara erişimin olmaması hali olarak açıklayan Vora ve Pimble ${ }^{25}$, siyasi özgürlükleri, karar verme mekanizmalarında varlıkları ve kişisel güvenlikleri olmayan yoksulları ise durumlarını değiştiremeyen ve toplumsal yaşama katılamayan bireyler olarak tanımlarlar. İnsanların ekonomik, sosyal ve siyasi güç ve kaynaklara erişememeleri nedeniyle oluşan yoksunluklar nedeniyle yoksul olduklarını ve yoksul kaldıklarını belirtirler.

İnsanın eğitim, sağlık, çalışma, evlenme, özgürce işini seçme, düşünme, bilgi edinme, ifade vb. temel hak ve özgürlüklerinin yanında, bir de insan onuruna yaraşır biçimde yaşaması amacıyla kalkınma hakkı doğmuştur. ${ }^{26}$ Bu hakkın doğuşu yeni bir yaklaşımla gerçekleşmiştir. 1980'li yıllarda tüm haklardan tam olarak yararlanmak için gerekli çerçeveyi sağlayan ek bir insan hakları kategorisi tanınmıştır: barış ve güvenlik hakkı, kalkınma hakkı ve sağlıklı çevre hakkı. Bu haklar uluslararası iş birliğini gerektirdiği ve toplumun inşası amacına sahip olduğu için dayanışma hakları

24 Claudia Wallin, “Zengin ve Fakire Eşit Fırsat Tanıyan Finlandiya Eğitim Sistemi Nasıl Dünyaya Örnek Oldu?”, erişim Ekim 10, 2018. https://www.bbc.com/turkce/haberler-dunya-45626450.

25 Alpa Vora ve Minar Pimple, Yoksul Olmama Hakkı, İnsan Haklarını Anlamak içinde, çev. Mehveş Bingöllü Kılcı, Graz: Avrupa İnsan Hakları ve Demokrasi İçin Eğitim ve Araştırma Merkezi (ETC) Yayını, 2006, s.103. 26 Vecihi Timuroğlu, İnsan Hakları Sözlüğü, Ankara: Özkan Matbaacılık, 2007, s.248. 
olarak tarif edilebilir. ${ }^{27}$ Kaboğlu $^{28}$ bu hakları şu şekilde açıklamıştır:

Barış hakkı herkesin savaş suçları ve insanlık ve barışa karşı suçlara müdahale hakkı ile birlikte şiddet ve terörizmden korunma ve silahsılanma haklarını; gelişme hakkl, ekonomik, sosyal, kültürel, siyasal, sosyal ve hukuksal ilerleme hakkını, serbestçe kişiliğini geliştirme hakkını ve her topluluğun kültürel kimliğine saygı hakkını; çevre hakkı, herkesin ve toplu olarak bütün insanların sağlıklı, ekolojik olarak dengeli, ekonomik olduğu kadar sosyal, kültürel, siyasal ve hukuksal gelişimlerine elverişli bir çevre hakkını, insanlığın ortak mal varlığına saygı hakkı ise hiç kimsenin insanlığın ortak malvarlığı üzerinde münhasır bir mülkiyet hakkı talep edememesini ve bu çerçevede her insanın insanlığın ortak malvarlığından yararlanma hakkını ifade etmektedir.

1981 yılında yayınlanan Afrika İnsan ve Halkların Hakları Şartı, dayanışma haklarının bütünlüklü bir yaklaşım içerisinde tanındığı uluslararası bir belge olarak öne çıkmaktadır. Belgenin 20, 21 ve 22. maddeleri, kalkınma hakkını anlatır niteliktedir:

"Bütün haklar var olma hakkına sahip olacaktır. Bütün halkların sorgulanamaz ve devredilemez nitelikte kendi kaderini tayin hakkı olacaktır. Bütün halklar, ...kendi siyasal statülerini özgürce belirleyecek ve özgür olarak seçtikleri siyasaya uygun olarak ekonomik ve sosyal gelişmelerinin takipçisi olacaklardır (md. 20). Bütün halklar, kendi doğal zenginlik ve kaynaklarını özgür olarak kullanacaklardır. Bu hak, münhasıran halkın çıkarları için kullanılacaktır. Hiçbir halde bir halk bu haktan yoksun bırakılmayacaktır (md. 21). Bütün halkların, özgürlük ve kimliklerini usulünce dikkate alarak ve insanlığın ortak mirasından eşit olarak yararlanarak, ekonomik, sosyal ve kültürel alanlarda gelişmeye hakları olacaktır (md. 22)"”

Ancak kalkınmayı bir hak olarak tanımlayan temel metin 1986 tarihli BM Kalkınma Hakkına İlişkin Bildirgedir. Bildirge, Kalkınma Hakkının vazgeçilmez bir insan hakkı olduğunu ve kalkınma sağlanması için fırsat eşitliğinin hem uluslar ve hem de ulusu oluşturan bireyler bakımından bir hak olduğunu ortaya koyan bir dönüm noktasıdır. Bildirgenin birinci maddesinde kalkınma hakkının "her insanın ve bütün halkların, bütün insan haklarının ve temel özgürlüklerin tam olarak gerçekleşeceği bir ekonomik, sosyal, kültürel ve siyasal gelişmeye katılma, katkıda bulunma ve bundan yararlanma hakkına sahip olması nedeniyle vazgeçilmez bir insan hakkı olduğu" ifade edilmektedir. Bildirgenin ikinci maddesinde "insanın kalkınmanın temel öznesi; kalkınma hakkının aktif katılımcısı ve yararlanıcısı olması” gerektiği belirtilirken altıncı maddede ise insan haklarının ve temel özgürlüklerin bölünmez ve birbirine bağımlı olduğu vurgulanarak devletler kişisel, siyasal, ekonomik, sosyal ve kültürel hakların uygulanmasına, sağlanmasına ve korunmasına aynı dikkat ve acil hassasiyet göstermek ile yükümlü tutulmuşlardır. ${ }^{29}$

27 Wolfgang Benedek, İnsan Hakları Sistemine Giriş, İnsan Haklarını Anlamak içinde, çev. Mehveş Bingöllü Kılcı, Graz: Avrupa İnsan Hakları ve Demokrasi İçin Eğitim ve Araştırma Merkezi (ETC) Yayını, 2006, s.42. 28 İbrahim Özden Kaboğlu, Özgürlükler Hukuku: İnsan Haklarının Hukuksal Yapısı, İstanbul: İmge Kitabevi, 2002 , s.28.

29 Kalkınma hakkı, Viyana Sonuç Bildirgesi (1993) ile BM Binyıl Bildirgesinin yanı sıra Rio Bildirgesi, Gündem 
Kalkınma hakkı esasen gelişmekte olan ülkeler ile birlikte anılan ve ekonomik anlamda geri kalmışlık ile ilişkilendirilen bir olgudur. Olgunun uluslararası boyutuna ve geri kalmışlığın arka planına bakıldığında bu hakkın, insan haklarının uluslararası aktörlere sorumluluklar yüklediği görülecektir. ${ }^{30}$ Kalkınabilmek için uluslararası mali desteklere duyulan gereksinim, yardım eden ülkelerin dikte ettiği politik adımları atılması koşuluna bağlanarak politik bir baskı aracı olarak kullanılabilmektedir. $\mathrm{Bu}$ ise ülkelerin egemenliklerine ve özgürlük alanlarına müdahale niteliği taşıyabilmektedir.

Kalkınmak ülkeler için olduğu gibi bireyler açısından da hem bir hak hem de özgürlük alanıdır. Bu hak ve özgürlük alanı ise insanların ve toplumların kalkınma için nispeten adil fırsatlara sahip olabilmesi ile şekillenir. Kalkınmanın hem amacı hem de arac1 olarak özgürlüklerin genişlemesine işaret eden Sen’e ${ }^{31}$ göre ise “özgürlükle bireysel olarak sahip olduğumuz eylem özgürlüğü, bize sağlanan toplumsal, siyasal ve iktisadi fırsatlar tarafından kaçınılmaz biçimde sınırlanır ve kısıtlanır. Bireysel eylemlilik ile toplumsal düzenlemeler arasında birbirini tamamlayan derin bir ilişki vardır.” Kuşkusuz ekonomik kalkınmanın adil bir gelir dağılım politikası ile gelir yoksulluğunu azaltıcı bir sosyal politikaya dönüşemediği durumlarda yoksulluk, yoksul bireylerin yaşamlarında varlığını sürdürebilmektedir.

Bu durum yalnızca gelirin yeniden dağılımı (asgari ücret, vergi politikaları vb.) ile sınırlandırılabilecek bir sorun da değildir. Bu dağılımı da belirleyecek olan siyasi ve sosyal hakların kullanımıdır ki, yoksul insanların bu bağlamda hareket alanları sınırlı düzeydedir. Örneğin örgütlenme hakkını etkili bir şekilde kullanamayan yoksul bireyler, kalkınma hakkını kullanabilmek için belirleyici olan politik ve ekonomik karar alma süreçleri sınırlı düzeyde etkileyebilmektedir. Kalkınmanın bir hak ve özgürlük alanı olarak genişlemesi, bireyden topluma uzanan bir süreçtir ve elbette hakların bir bütün olarak ele alınmasını gerektirmektedir.

Ancak Moyn'un işaret ettiği gibi toplumsal ve ekonomik hakların gidişatındaki en çarpıcı paradokslardan biri, insan haklarının gelmesiyle birlikte bu hakların gerilemiş olmasıdır. ${ }^{32}$ Moyn gelişme hakkını 'acılar içindeki insanlığın hakkı' olarak nitelendirirken, mantıksal olarak küresel yoksullaşmaya karşı yeterli olabilecek bir insan hakları vizyonu bulma projesine harcanan teorik ve öğretisel enerjinin, insan haklarının kat etmesi gereken mutlakıyet karşıtı keşiflere olan uzaklığını ortaya koyduğunu belirtmektedir. ${ }^{33}$

İnsan hakları yazını ve hukuku, hak ihlalleri ile mücadelede gerek birey gerekse toplum düzeyinde insan yaşamını zenginleştirmek, özgürleştirmek ve geliştirmek

21, Kopenhag Bildirgesi, Pekin Eylem Platformu, Habitat Gündemi ve Avrupa 2020 girişimi gibi, hükümetlerin yoksullukla mücadele ve uluslararası kalkınma amaçlı çalışmalarında da karşılık bulmuştur.

301991 Moskova İnsani Boyut Konferansı Belgesi’nin giriş kısmında ise insan hakları, temel özgürlükler, demokrasi ve hukukun üstünlüğüne saygı göstermenin yalnızca devletlerin değil uluslararası düzenin de temellerinden biri olduğu belirtilmiştir.

31 Sen, Özgürlükle Kalkınma, s. 14.

32 Moyn, Son Ütopya: Tarihte İnsan Haklart, s.188.

33 Moyn, Son Ütopya: Tarihte İnsan Hakları, s.192. 
için geniş bir külliyat ortaya koymaktadır. Buna rağmen yoksulluk kalkınma hakkı ihlallerinin hem nedeni hem de sonucu olarak bireylerin ve toplumların kapasitelerini geliştirmelerinin önüne set çekmektedir. Bir hak ihlali olarak yoksulluk yalnızca kalkınmanın değil adalet, özgürlük ve eşitliğe dayalı olarak insan haklarının somut bir yaşam pratiğine dönüşememesinin de yapısal nedenlerinden biridir. Nitekim yoksulluk, erişilebilen firsat ve kaynakların üretken olmaması ve yaratılan artı değerden alınan payın, kalkınmak bir yana, ancak günü kurtarabilecek bir büyüklüğe sahip olması ile nedeniyle bilhassa uluslararası düzeyde mali transferlere bağımlı ekonomiler ve yönetim anlayışlarıyla kendini tekrarlamaktadır.

\section{Direnme Hakkı}

Bugün sahip olduğumuz insan hakları kusurlu ve eksiktir, çünkü insanların ister bireysel ister toplumsal düzeyde olsun, en alttan en üste insani görevleri ile haklarını gündelik yaşamlarında hayata geçirme sorumluluğu vardır. ${ }^{34} \mathrm{Bu}$ sorumluluğu yerine getirmenin bir nedeni olarak direnme hakkı kullanmanın günümüz dünyası açısından pek çok haklı nedeni bulunmaktadır. Uluslararası Af Örgütü Genel Sekreteri Irene Khan’ın özetlediği üzere, "963 milyon insan her gece aç bir şekilde yatağına gidiyor. Bir milyar insan gecekondularda yaşıyor. Her dakika, bir kadın çocuk doğururken hayatını kaybediyor. 2,5 milyar insanın yeterli sağlık ve temizlik hizmetlerine erişimi yok. Bu sebeple her gün 20 bin çocuk ölüyor." ${ }^{35}$

Tüm bu yoksunluklar toplumsallaşırken insanları edilgenleştiren ve etkisizleştiren eşitsizliklere karşı duruş farklı bir hak kavramı ile ifade bulmaktadır: "direnme hakkı". Bu hak, İnsan ve Yurttaşlık Hakları Bildirgesinin (1789) ikinci maddesinde sıralanan doğal ve zaman aşımına uğramayan haklar arasında yer alır. John Locke’a değin resmiyetten yoksun ve sivil toplum yapısına yabancı bir hak olarak kalan direnme hakkını Locke, sivil bir hükümetin varlık nedeninin, direnme hakkını gerçekliğe dönüştürmek olduğunu savunmuştur. ${ }^{36}$ İHEB' in önsözünde "insanın istibdat ve baskıya karşı son çare olarak ayaklanmaya mecbur kalmaması için insan haklarının bir hukuk rejimi ile korunması esaslı bir zorunluluk" olarak kabul edilmiştir.

Hakların kullanımını doğrudan ya da dolaylı olarak olanaksız kılan her engel, bireyin toplumdaki varlı̆̆ını da kendi kaderini tayin edebilme iradesini de kuşatır. Bu kuşatma karşısında direnme hakkı doğal bir insan hakkı olarak belirir. Bu hakkın hukuki düzlemde karşılık bulması öncelikli olarak insan haklarının yargı yoluyla korunabilir olması ile ilişkilidir; ancak yalnızca bununla sınırlı değildir. Hakların sosyal, siyasi ve ekonomik açıdan da korunabilmesi olanaklıdır. İnsan hakları duyarlılı̆̆ının ve bu duyarlılığa dayalı hukuki mekanizmaların gelişmesi ve işlemesi, yalnızca gerçek kişiler değil tüzel kişiler bağlamında da insan hakları ihlallerine karşı direnme hakkının sorumlu bir yaklaşımla kullanılmasına bağlıdır.

34 Matthias Lutz Bachmann ve Amos Nascimento, İnsan Hakları ve Kozmopolitik Paradigmaları: Haklardan İnsanlığa, der., Matthias Lutz-Bachmann ve Amos Nascimento, İstanbul: Koç Üniversitesi Yayınları, 2016, s.182. 35 Bachmann ve Nascimento, İnsan Hakları ve Kozmopolitik Paradigmaları, s.169.

36 Philippe Raynaud ve Stephane Rials, Siyaset Felsefesi Sözlüğ̈̈, çev., İsmail Yergüz vd., İstanbul: İletişim Yayınlar1, 2003, s.236-241. 
Yoksul insanların yoksulluğa karşı direnme hakkından söz edebilir miyiz? Ki Mbon$\mathrm{da}^{37}$ yoksulluğu acıyla özdeşleştirir ve şu sözlerle anlatır: "Yoksulluk acıdır; yetersiz yiyecekten ve uzun çalışma saatlerinden kaynaklanan fiziksel acıdır; günlük yaşamda aşağılanmaktan ve güçsüzlükten kaynaklanan duygusal acıdır; en temel ihtiyaçları karşılamak için yapılan çaresiz seçimler nedeniyle ahlâki acıdır.” Peki insan, kendisine acı ve esaret veren yoksulluğa karşı direnme hakkına sahip midir? Kuşkusuz sahiptir. Zizek'in ${ }^{38}$ ifadesiyle: “dünyanın dört bir yanındaki, 'tarihin dışına düşmüşs, Birinci Dünya kapitalizminin modernleşme projelerinden bilinçli olarak dışlanmış ve ümitsiz vaka olarak üstü çizilmiş olan kalabalık nüfuslar” olan yoksul insanların "dünyanın her neresinde olursa olsun insan hakları mücadelesi açısından yoksulluğa ve zulme karşı direnme hakkı temel bir hak olarak büyük önem taşımaktadır”.

İnsanlık tarihine yön veren semavi dinlerde inananları zulüm, esaret ve batıl inançlar karşısında ayağa kaldıran, direnme hakkıdır. Örneğin İslam inancında “iyiliği emretmek ve kötülükten alıkoymak” muhalefetin meşruluk dayanaklarındandır ve Allah müminleri, kötülük karşısında susmamaya yönlendirir. ${ }^{39}$ Haksızlıklar karşısında susmamak ve hakkı sahibine teslim etmek bu inancın bir gereğidir. Diğer taraftan dünyanın en yoksul ülkeleri arasında, ihtiyaç dışında kalan her kazançta yoksulların hakkı olduğunu bildiren İslam inancına mensup insanların yaşadığı ülkeler yer almaktadir.

Yoksulluk, her dönem insanla ilgilidir; insani bir meseledir ve bir insan hakları ihlalidir. Bu ihlal, onurlu yaşam hakkını yaşanabilir kılacak olanaklardan yalıtılan yaşamlarla kuşatma alanlarını yaratarak varlığını sürdürmüştür. Küntay ${ }^{40}$ bu kuşatma alanının insanı dâhi metalaştıran ihlal ahlakını şu sözlerle açıklar:

"İnsan, hak sahibidir. Kişilik, hak ve borçları taşıyabilme yeteneğidir. Birey, hak sahibi olduğu için kişidir. Hakkın konusu ise, nesneler (eşya) dir. Tarih boyunca kimi zaman eşya kavramının genişleyerek kişileri de kapsadığını görmekteyiz. Söz konusu kurum köleliktir, başka bir deyişle, birey tıpkı nesneler gibi alınıp satılmıştır. Köle, en düşük ya da karşılığı olmayan işlerde çalışmaya zorlanmış, dayak yemiş, kamçılanmış, ailesi bölünerek pazarda haraç mezat satılmıştır. Kölenin öldürülmesi birçok yerde suç sayılmamış, mülk sahibi olması, yasalarla engellenmiştir.”

Topçu'nun "birey ve toplum ahlaki varlıklardır; fert hayvan olmaktan, toplum da sürü haline gelmekten onunla kurtulur..." ${ }^{41}$ ifadesi ile belirttiği gibi insanın ve toplumların her bireyin insanca ve sahip olduğu onura yakışır şekilde yaşaması için direnmesi bir haktır.

37 Ernest-Marie Mbonda, Poverty as a Violation of Human Rights: Towards a Right Non-poverty, Unesco 2004, Oxford: Blackwell Publishing, 2004, s.278.

38 Slovaj Zizek, Capitalism can no Longer Afford Freedom, ABC Religion and Ethics, erişim 17 Ekim, 2018, http:// www. abc. net. au/religion/articles/2012/05/25/3511327. htm.

39 Şeniz Anbarlı, “Baskıya Karşı Direnme Hakkı ve Sivil İtaatsizlik”, Yayınlanmamış Doktora Tezi, Dokuz Eylül Üniversitesi, 2006, s.153-154.

40 Esin Küntay, “21. Yüzyılda Çağdaşlık ve Köleci Uygulamalar Paradoksu”, Yoksulluk, Şiddet ve İnsan Hakları, der., Yasemin Özdek, Ankara: TODAİE Yayınları, 2002, s.148

41 Mustafa Kök, Nurettin Topçu ve Rönesansımız, Nurettin Topçu’ya Armağan. İstanbul: Dergâh Yayınları, 1992, s. 103 . 
Ahlaki talepler niteliğinde olan insan hakları özünde siyasi nitelik taşırlar. İnsan hakları doktrininin temel işlevi, siyasi iktidarların keyfi müdahalelerine engel teşkil edip iktidarı sınırlandırmak; iktidarı bireyin rızasına dayandırarak bireyin kendini gerçekleştirebilmesinin yolunu açmak ve devletin bütün uygulamalarında insan haklarını koruma duyarlılığıyla hareket etmesini sağlamaktır. ${ }^{42}$ Siyasal yeğlemelerini toplumun isteklerinin sürekli önüne koyan, politikasını halka karşın halk için söylemine dayandıran, toplumdan gelen sesleri dinlemeyen, halkına zulmeden bir iktidar, anayasa ya da öteki pozitif hukuk kurallarında yazılı olsa da olmasa da, halkın doğal hukuktan gelen direnme hakkının doğumuna neden olacaktır. ${ }^{43}$

\section{Yoksulluğa Hak Temelli Yaklaşım}

Yeryüzünde yaşayan 7,6 milyar kişi arasında en zengin sekiz kişinin serveti, dünyadaki en yoksul 3,6 milyar insanın toplam servetine eşit hale gelmiştir. ${ }^{44}$ Dünyanın yoksulluk konusunda içinde bulunduğu derin çelişki bize yoksul olmama hakkının ve doğurduğu yükümlülüklerin sahip olduğu uluslararası bağlam ile birlikte düşünülmesi gerektiğini işaret etmektedir. Sorulması gereken soru, Fraser'in ${ }^{45}$ ifade ettiği şekliyle, oldukça basittir:

"Adaletin öznesi kim? Kimlerin çıkarlarını ve ihtiyaçlarını dikkate almaya değer? Ekonomik yeniden dağıtım, kültürel tanınma ya da politik temsil söz konusu olduğunda kimler, adalet talep edebilenler arasında yer alabiliyor?”

$\mathrm{Bu}$ sorular, yoksulluk ve insan hakları ilişkisinde temel hakların yanı sıra işlevsellikleri bakımından iki kritik hakla da doğrudan ilişkilidir: kalkınma hakkı ve direnme hakkı. Çünkü yoksulluğun yarattığı hak ihlallerinin önüne geçebilmek ancak sömürü temelli bir düzenden sosyal ve ekonomik hakların bir bütün olarak yasallaşabildiği ve kurumsallaşabildiği hak temelli bir düzene geçişle ve bu geçişin adil bir kalkınmayı ve hak ihlalleri karşısında direnme hakkını esas alan bir hukuk sistemine dayalı olarak gerçekleşmesi ile olanaklıdır. Nitekim yoksulluk ve insan hakları ilişkisi, yoksulluk mirasını nesilden nesile devralan toplumların kalkınamaması ve yoksulluğa karşı direnememesi ile karakterizedir.

$\mathrm{Bu}$ bağlamda neoliberal rotadaki ortak özellik eşitsizlik ve yoksulluğun artışıdır ${ }^{46}$. Dünyanın pek çok ülkesinde yoksul insanlar bir dizi sorunu birlikte yaşamaya mahkûmdur: İşsizlik, düşük gelir, kötü yerleşim koşulları, kötü beslenme, sağlık hizmetleri ile kültür, spor, dinlenme ve eğitim olanaklarına ulaşmada yaşam boyu karşılaşılan engeller... Yoksullar iktisadi, toplumsal ve kültürel yaşamda diğer insan-

42 Halil Kalabalık, İnsan Hakları ve Kamu Özgürlükleri, Eskişehir: Açıköğretim Fakültesi Yayınları, 2018.

43 Yılmaz Aliefendioğlu, "Direnme Hakkı", Yoksulluk, Şiddet ve İnsan Hakları, der., Yasemin Özdek, Ankara: TODAİE Yayınları, 2002, s.405.

44 S. Rıdvan Karluk, "Adaletsiz Bir Dünyada Yaşıyoruz: En Yoksul Yüzde 20 Günde 1.90 Dolarla Geçiniyor", erişim 29 Ekim, 2018, https://www.turkishnews.com/tr/content/2018/01/26/adaletsiz-bir-dunyada-yasiyoruzen-yoksul-yuzde-20-gunde-1-90-dolarla-geciniyor/.

45 Hugh Frazer and Eric Marlier, "Minimum Income Schemes Across EU Member States", Synthesis Report, EU, Network of National Independent Experts on Social Inclusion, 2009.

46 Gosta Esping-Andersen, "Altın Çağ Sonrası? Küresel Bir Ekonomide Refah Devleti İkilemleri", Sosyal Politika Yazıları, der. Ayșe Buğra ve Çağlar Keyder, İstanbul: İletişim Yayınları, 2013, s.80. 
ların doğal yaşam akışı içerisinde yapageldikleri etkinliklere hakkıyla katılamazlar ve temel haklarına ulaşımda zorluklar yaşayabilirler. ${ }^{47}$ Birçok insan hakkı ihlalinin temelinde yatan yoksullukla ilgili durumlar yetersiz beslenme, insanca yaşam için gerekli bir eve sahip olmama, sağlıksız koşullar, neredeyse tek temel hak görülen yaşama hakkının korunmasını da olanaksız kılar. ${ }^{48}$

Fiziksel gereksinimlerin yeterli bir biçimde sağlanamamasının yanı sıra, yoksulluğun yarattığı güçsüzlük duygusu, sesini duyuramama, giderek toplumsal yalıtılmışlık ve marjinalleşmeye itilme, iki önemli sonuç ortaya koyar. İlki, yoksul kişilerin gelirlerinde büyük değişmelerle karşı karşıya kalma riski, ki bu riske karşı çok duyarlıdırlar, diğeri ise yaşadıkları güçsüzlük ve marjinalleşme yüzünden seslerini duyurabilecek siyasi güce sahip olmadıkları için toplumdaki eşitsizliğin ve kimi grupların dışlanmasının giderek yaygınlaşmasıdır. ${ }^{49}$

Yoksulluğun hem nedeni hem de sonucu olarak eğitimsizlik ve işsizlik, yalnızca gelir dağılımı bakımından değil, daha önemlisi, yoksullara açık olan ekonomik, toplumsal ve siyasal firsatlar bakımından da eşitsizliklerin ortaya çıkması ve bu eşitsizliklerin kendi kendini sürdürecek biçimde yaygınlaşmasını da beraberinde getirmektedir. $\mathrm{Bu}$ durum 'kalıcı eşitsizlikler' nedeniyle kalkınma hakkının ihlaline ve politik düzlemde, sistematik olarak daha güçlü ve etkili kişiler, gruplar ya da topluluklar lehine işleyen kurumlar ve yasalar nedeniyle hak ihlallerine direnmek için gerekli bilince ve hukuki araçlara erişimde engellere neden olmaktadır.

Kapani'nin ${ }^{50}$ belirttiği gibi yaşama ve sağlık hakları gibi en doğal ve ilkel hakları bile güvenlik altına alınmamış olan aç ve yoksul kitlelerin "insan hakları yılından, insan hakları gününden, bildirilerden, beyannamelerden, sözleşmelerden haberleri yoktur. Onları her şeyden önce insanlıklarından haberdar etmek lazımdır. İnsan haklarının gerçekten evrenselliğinden söz edebilmek için bu yoksul yı̆̆ınları hiç değilse en ilkel haklarına kavuşturmak lazımdır."

Yoksullukla mücadelenin hak temelli bir yaklaşım çerçevesinde ele alınabilmesi için öncelikle yoksulluğun bir insan hakları sorunu olarak kabul edilmesi gerekmektedir. Bu noktada hakların insanın evrenselliğiyle olan genel ilişkisine de bambaşka bir sşık tuttuğundan, hakların devletle olan temel bağını kurabilmek önemlidir. ${ }^{51}$ Bu bağ temel olarak yoksul olmayan karar alıcıların, yoksulların gelir dağılımı ve bölüşümünde sahip oldukları pay üzerinde alacakları kararlar açısından belirleyici niteliktedir. Nitekim yoksul insanlar kendilerini var edebilmek için sahip oldukları hakları kullanmak, bu hakların varlığından bihaber yaşamlarında, yaşamda kalma mücadelesi vermektedir. Bu mücadelede devletle yoksul birey arasındaki bağın bilhassa sağlık,

47 Adaman ve Keyder, Türkiye’de Büyük Kentlerin, Gecekondu ve Çöküntü, s.5.

48 Harun Tepe, "Sosyal Haklar ve İnsan Hakları: Sosyal ve Ekonomik Haklar Olmadan İnsan Hakları Korunabilir mi?”, Sosyal Haklar Bildiri Kitabı, 2009, s.103.

49 Ravi Kanbur and Lyn Squire, The Evolution of Thinking About Poverty: Exploring the Interactions, Frontiers of Economic Development: The Future in Perspective, ed., Meier Gerald and Joseph Stiglitz, New York: World BankOxford University Press, 2000, s.209.

50 Münci Kapani, "Dünyada ve Türkiye’de İnsan Haklarına Genel Bakış”, (Türkiye’de İnsan Hakları Semineri, Aralık 1968), Ankara: Ankara Üniversitesi Hukuk Fakültesi Yayınları, 1970, s.5.

51 Moyn, Son Ütopya: Tarihte İnsan Hakları, s.188. 
eğitim ve sosyal güvenlik hakları açısından süreklilik arz etmesi önem taşımaktadır.

Hak temelli yaklaşım, bireylerin haklarını bilerek ve savunarak güçlenmesinin bir yoludur ve bu hakların karşılanmasından, korunmasından ve yerine getirilmesinden sorumlu kişi ve kuruluşların yapabilirliklerini ve hesap verebilirliklerini geliştirir. Bunun anlamı, insanların sahip oldukları haklara ve bu hakların sunduğu firsatlara ilişkin farkındalığı arttıkça insan haklarına ilişkin karar alma ve yön verme süreçlerine daha etkin katılım sağlayacak olmasıdır. ${ }^{52}$ Bu bilinç ve duruş ise kuşkusuz eğitim hakkının etkili bir şekilde kullanılması ile mümkündür. Yoksullukla hak temelli mücadelede, insan hakları bilgi ve anlayışına sahip kişilerin karar alma süreçlerinde yer alabilmesi yine hak temelli yaklaşıma dayanan eğitim ve yönetim sistemlerinin gelişmesini ve yaygınlaşmasını gerektirir.

Bugün toplumsal kutuplaşmanın, derinleşen eşitsizliğin, gitgide artan insan yoksulluğunun, sefaletinin ve zulmün en göze çarpan vakalarının altında yatan şey, 1,5 asır önce Marx tarafindan öne sürüldüğ̈ gibi bir sömürü olmaktan ziyade, dışlanmadır. ${ }^{53}$ Kapitalist ekonominin kendi küresel düzleminde sömürüden dışlamaya doğru kayıyor olması en çok da insan hakları idealini tehdit etmektedir.

İnsan hakları ideali gerçekten katılımcı bir toplumda gerçekleşebilir. Bu katılım yoksul bireyleri dışarda bırakan bir insan hakları anlayışı ile şüphesiz sağlanamaz. Yoksul bir bireyin toplumun onurlu bir üyesi olarak kendisini gerçekleştirebilmesi ve yaşamına yön verebilmesi için eğitime, çalışmaya, kalkınmaya ve onu yoksullaştıran koşullara karşı direnmeye hakkı bulunmaktadır. Ife'nin de belirttiği gibi katılımcı demokrasinin bazı biçimleri bu nedenle insan hakları için bir önkoşuldur. ${ }^{54}$ Küreselleşen dünyada, gücünü giderek daha da artıran küresel ekonomik güçler ve gelişen küresel iletişim olanakları ile birlikte, artık küresel katılımcı demokrasinin bir biçimini düşünmek ${ }^{55}$ insan haklarının geleceği için kritik bir dönemeçtir. Örneğin insan haklarının tanımlayıcısı ve bağlamsal bir ifadesi olarak ihtiyaçların kim tarafından, neye göre tanımlandığı ve nasıl meşru kabul edildiği katılımcı demokrasi açısından önem taşımaktadır: Geliştirici bir eğitim, insana yakışır koşullarda çalışma, kapsayıcı bir kalkınma ve demokratik yollarla direnme için ihtiyaçları tanımlama sorumluluğunun paylaşılmasına yoksul bireyleri dâhil eden ve önlerindeki yapısal engelleri kaldıran bir diyalog ortamı katılımcı bir toplumun ve demokrasinin yansımalarıdır.

Bu bağlamda yoksulluğa hak temelli yaklaşmak ihtiyaçları yadsıyan değil, aksine ihtiyaçların kaçınılmaz olarak haklarla bağlantılı olduğunun altını çizen bir yaklaşımdır. Maslow, "Motivasyon ve Kişilik" kitabının ikinci basımının önsözünde, tanımladığı ihtiyaçların aslında haklar olarak görülebileceğini öne sürer. İhtiyaçlar hakları barındırdığına göre, insan hakları açısından kendini geliştirme hedefini tüm insan-

52 Olga Zengen and Marina d'Engelbronner, Guide to Corporate Human Rights Impact Assessment Tools, Business in Human Rights Center, 2009; Haki Zetu, Economic, Social and Culturel (ESC) Rights in Practice, Amnesty International Netherlands, 2010.

53 Zygmnut Bauman, Kimlik: Benedetto Vecchi Tarafindan Gerçekleştirilen Söyleşiler, çev. Mesut Hazır, İstanbul: Heretik Yayınları, 2017, s.54.

54 Ife, İnsan Hakları ve Sosyal Hizmet, s.165.

55 Barry Holden, Global Democracy: Key Debates, London: Routedge, 2000. 
ların sahip olması gereken bir hak olarak görebiliriz. Diğer taraftan tüm insanlara tek tip evrensel insan ihtiyaçlarının dayatılması çeşitliliğe izin vermeyeceği için göreceli bir ihtiyaç yaklaşımı temel insan haklarının farklı bağlamlarda farklı şekillerde karşılanmasına yapılmış bir çağrıdır. ${ }^{56} \mathrm{Bu}$ nedenle her hakkın kültürel, toplumsal, siyasal, ekonomik, coğrafik vb. uygulama bağlamında işaret ettiği ihtiyaç farklılaşacaktır.

\section{Sonuç}

İnsan onur ve haysiyetine yakışır, insanca yaşam koşullarına sahip olmak olanaksız değildir ancak yoksul insanların temel haklarını kullanabilmesi ve bunu sağlayacak araçlara erişimi önünde yapısal engeller bulunmaktadır. Bu engeller insanlık tarihine yön veren üretim, bölüşüm ve tüketim ilişkilerine bağlı olarak kimi zaman kabuk değiştirmiş, kimi zaman verilen mücadelelerle aşılmış, kimi zaman ise kanıksanmış ve yeniden üretilmiştir. Böylece yoksulluk ve yarattığ 1 hak ihlalleri, insanlık tarihi boyunca var olagelmeyi sürdürmüştür.

İnsan hakları hukukun zorunlu ve imkânsız adalet iddiasıdır. ${ }^{57}$ Tüm imkânsızlığına rağmen bu iddia, yoksul ya da zengin her insanın ırk, renk, cinsiyet, dil, din, siyasi düşünce, etnik köken gibi ayrımlar gözetilmeksizin temel haklarını kullanabilmesi ve bunu sağlayacak araçların geliştirilmesi idesine dayanmaktadır. Bu ideyi Mozi (M.Ö. 470-391) yüzyıllar önce "Dünyadaki herkes birbirini sevdiğinde güçlüler güçsüzleri ezmeyecek, çoğunluk azınlığa baskı yapmayacak, zengin yoksulla alay etmeyecek, itibarlılar düşmüşleri küçümsemeyecek ve kurnazlar safları kandırmayacak" ${ }^{58}$ sözleri ile ifade etmiştir.

Anahtar bir kavram olarak eşitlik, insan haklarının adil şekilde erişilmesi ve herkesin insan onuruna yakışır bir yaşam sürme şansının var olması için insanlık tarihinin ortaya koyduğu kadim değerlerinden biridir. Eşitlik, sosyal adalet ve insan hakları ile birlikte mümkündür ve yoksulluk, eşitsizliklerin hem nedeni hem de sonucu olarak hak ihlallerine ve sosyal adaletsizliklere zemin oluşturmaya devam etmektedir. Hakları hakkaniyetle gözetilmediği için yoksullaşan insanlar, yoksul oldukları için haklarına sahip çıkamayan kitlelere ve eşitsizliklerin nesnesine dönüşmektedir.

Şu hâlde yoksulluğu herkes için ve kalıcı olarak ortadan kaldırabilmenin yolu, meseleye hak temelli yaklaşmaktan geçmektedir. Nitekim yoksulluk esasen insanca yaşama hakkının ihlalidir ve varlığını 'kalıcı eşitsizliklerin' korunması ile sürdürmektedir. Yoksul olmamak ve yoksul kalmamak açısından işlevleri açısından öne çıkan çalışma, eğitim, kalkınma ve direnme hakları başta olmak üzere insan haklarının bir bütün olarak sosyal ve ekonomik politikaların ana bileşeni olarak işlev görmesi bir tercih değil, zorunluluktur.

56 Ife, İnsan Hakları ve Sosyal Hizmet, s.122-124.

57 Costas Douzinas, İnsan Haklarının Sonu, çev., Umre Deniz Tuna ve Kasım Akbaş, Ankara: Dipnot Yayınları, 2018, s. 410.

58 Rhonda Byrne, Secret the Power, çev. Beril Tüccarbaşığlu Uğur, İstanbul: Artemis Yayınları, 2011, s. 189. 


\section{Kaynakça}

Adaman, Fikret ve Çağlar Keyder. “Türkiye’de Büyük Kentlerin, Gecekondu ve Çöküntü Mahallelerinde Yaşanan Yoksulluk ve Sosyal Dışlanma”. Sosyal İşler ve Fırsat Eşitliği Dairesi Araştırma Raporu, VC/2005/0155. İstanbul, 2006.

Aktan, Coşkun Can. Yoksullukla MücadeleStratejileri.Ankara:Hak-İşKonfederasyonu Yayınları, 2002.

Aliefendioğlu, Yılmaz. "Direnme Hakkı". Yoksulluk, Şiddet ve İnsan Hakları. Der. Yasemin Özdek. Ankara: TODAİE Yayınları, 2002.

Bachmann, Matthias Lutz ve Amos Nascimento. İnsan Hakları ve Kozmopolitik Paradigmaları: Haklardan Insanlı̆̆a. Der., Matthias Lutz-Bachmann ve Amos Nascimento. İstanbul: Koç Üniversitesi Yayınları, 2016.

Bauman, Zygmunt. Kimlik: Benedetto Vecchi Tarafindan Gerçekleştirilen Söyleşiler. Çev., Mesut Hazır. İstanbul: Heretik Yayınları, 2017.

Benedek, Wolfgang. "İnsan Hakları Kavramı ve İnsan Haklarının Niteliği”. İnsan Haklarını Anlamak. Çev. Mehveş Bingöllü Kılcı. Graz: Avrupa İnsan Hakları ve Demokrasi İçin Eğitim ve Araştırma Merkezi Yayını, 2006.

Anbarlı, Şeniz. "Baskıya Karşı Direnme Hakkı ve Sivil İtaatsizlik”. Doktora Tezi, Dokuz Eylül Üniversitesi, 2006.

Benedek, Wolfgang. “İnsan Hakları Sistemine Giriş”. İnsan Haklarını Anlamak. Çev. Mehveş Bingöllü Kılcı. Graz: Avrupa İnsan Hakları ve Demokrasi İçin Eğitim ve Araştırma Merkezi Yayını, 2006.

Berk, Ferit. Toplumsal ve Bireysel Sorunlara Giriş. Çağımız Dizisi: 5. İstanbul: Sokak Kitapları Yayınları, , 2014.

Buğra, Ayşe ve Çağlar Keyder. "Yeni Yoksulluk ve Türkiye'nin Değișen Refah Rejimi”. BM Kalkınma Programı İçin Hazırlanan Yayınlanmamış Proje Raporu. İstanbul, 2003.

Douzinas, Costas. İnsan Haklarının Sonu. Çev., Umre Deniz Tuna ve Kasım Akbaş. Ankara: Dipnot Yayınları, 2018.

Erkilet, Alev. "Sınıf-Altı: Kuramsal Tartışmalar ve İstanbul Tarihi Yarımada’ya Uygulanma İmkânları”. Marmara Üniversitesi Sosyal Bilimler Enstitüsü Öneri Dergisi. 9/36 (2011): 137-146.

Esping-Andersen, Gosta. “Altın Çă̆ Sonrast? Küresel Bir Ekonomide Refah Devleti İkilemleri”. Sosyal Politika Yazıları. Der. Ayşe Buğra ve Çağlar Keyder. İstanbul: İletişim Yayınları, 2013.

Frazer, Hugh and Eric Marlier. "Minimum Income Schemes Across EU Member States". Synthesis Report, (EU Network of National Independent Experts on Social Inclusion, 2009).

Habermas, Jürgen. "The Concept of Human Dignity and the Realistic Utopia of Human Rights”. Metaphilosphy, 41:4 (2010):464-480.

Ife, Jim. İnsan Hakları ve Sosyal Hizmet. Çev. S. Erdem Türközü ve Aslıhan Aykara. Ankara: Nika Yayınevi, 2017.

Jonathan Bradshaw. “The Taxonomy of Social Need”. Ed. Richard Cookson, Roy 
Sainsbury and Caroline Gelndinning. Published Version, (2013): 71-82.

Jütte, Robert. Erken Modern Avrupa'da Yoksulluk ve Sapkınlık. Çev. Bengü Kurtege Sefer. İstanbul: Boğaziçi Üniversitesi Yayınevi, 2011.

Kaboğlu, İbrahim Özden. Özgürlükler Hukuku: İnsan Haklarının Hukuksal Yapısı. İstanbul: İmge Kitabevi, 2002.

Kalabalık, Halil. İnsan Hakları ve Kamu Özgürlükleri. Eskişehir: Açıköğretim Fakültesi Yayınları, 2018.

Kapani, Münci. “Dünyada ve Türkiyede İnsan Haklarına Genel Bakış”. Türkiyede Insan Hakları Semineri, 9-11 Aralık 1968. Ankara: Ankara Üniversitesi Hukuk Fakültesi Yayınları: 256, 1970, s. 1-9.

Karluk, S. Rıdvan. “Adaletsiz Bir Dünyada Yaşıyoruz: En Yoksul Yüzde 20 Günde 1.90 Dolarla Geçiniyor”. Erişim 29 Ekim, 2018. https://www.turkishnews.com/ tr/content/2018/01/26/adaletsiz-bir-dunyada-yasiyoruz-en-yoksul-yuzde-20gunde-1-90-dolarla-geciniyor/.

Kanbur, Ravi and Lyn Squire. The Evolution of Thinking about Poverty: Exploring the Interactions, Frontiers of Economic Development: The Future in Perspective. Ed. Meier Gerald and Joseph Stiglitz. New York: World Bank-Oxford University Press, 2000.

Karataş, Kasım. Yoksulluğun Küreselleşmesi ve Yoksulluğa Karşı Küresel Tavır, Değişen Türkiye'de Insan Hakları Açısından Sosyal Hizmetler. Der. Kasım Karataş. Ankara: Sosyal Hizmet Uzmanları Derneği Yayını No: 6, 2002.

Kök, Mustafa. Nurettin Topçu ve Rönesansımız. Nurettin Topçu’ya Armağan. İstanbul: Dergâh Yayınları, 1992.

Küntay, Esin. “21. Yüzyılda Çağdaşlık ve Köleci Uygulamalar Paradoksu”. Yoksulluk, Şiddet ve Insan Hakları. Der. Yasemin Özdek. Ankara: TODAİE Yayınları, 2002.

Mbonda, Ernest-Marie. Poverty as a Violation of Human Rights: Towards a Right Non-poverty. Oxford: Blackwell Publishing, 2004.

Moyn, Samuel. Son Ütopya: Tarihte İnsan Hakları. Çev., Firdevs Ev. İstanbul: Koç Üniversitesi Yayınları, 2016.

Raynaud, Philippe and Stephane Rials. Siyaset Felsefesi Sözlüğü. İstanbul: İletişim Yayınları, 2003.

Rhonda, Byrne. Secret the Power. Çev., Beril Tüccarbaşığlu Uğur. İstanbul: Artemis Yayınları, 2011.

Sen, Amartya. Özgürlükle Kalkınma. Çev: Yavuz Alagon. İstanbul: Ayrıntı Yayınları, 2004.

Şenses, Fikret. Küreselleşmenin Öteki Yüzü: Yoksulluk Kavramlar, Nedenler, Politikalar ve Temel Eğilimler. İstanbul: İletişim Yayınları, 2009.

Tepe, Harun. "Sosyal Haklar ve İnsan Hakları: Sosyal ve Ekonomik Haklar Olmadan İnsan Hakları Korunabilir mi?”. Sosyal Haklar Bildiri Kitabı. 2009: 97-104.

Timuroğlu, Vecihi. İnsan Hakları Sözlüğü. Ankara: Özkan Matbaacılık, 2007.

Tufan, Beril ve Kasım Karataş. "Yoksulluk ve Sosyal Hizmetler”. Sosyal Hizmet Sempozyumunda Sunulan Bildiriler, Hacettepe Üniversitesi Sosyal Hizmetler 
Yüksekokulu, Akdeniz Üniversitesi Sosyal Hizmetler Eğitim-Araştırma ve Uygulama Merkezi, Antalya, Ekim 9-11, 2003.

Vora, Alpa ve Minar Pimple. "Yoksul Olmama Hakkı". İnsan Haklarını Anlamak. Çev. Mehveş Bingöllü Kılcı. Graz: Avrupa İnsan Hakları ve Demokrasi İçin Eğitim ve Araştırma Merkezi Yayını, 2006.

Wallin, Claudia. "Zengin ve Fakire Eşit Fursat Tanıyan Finlandiya Eğitim Sistemi Nasıl Dünyaya Örnek Oldu?”. Erişim Ekim 10, 2018. https://www.bbc.com/ turkce/haberler-dunya-45626450.

Zengen, Olga and Marina d'Engelbronner. Guide to Corporate Human Rights Impact Assessment Tools. Business in Human Rights Center, 2009.

Zetu, Haki. Economic, Social and Culturel (ESC) Rights in Practice. Amnesty International Netherlands, 2010.

Zizek, Slavoj. "Capitalism can no Longer Afford Freedom". ABC Religion and Ethics. Erişim 17 Ekim, 2018. http://www.abc.net.au/religion/ articles/2012/05/25/3511327.html. 
İNSAN\&İNSAN, Y1l/Year 6, Sayı/Issue 21, Yaz/Summer 2019, 453-475

DOI: https://doi.org/10.29224/insanveinsan.494872

\title{
Rights Based Approach to Poverty
}

\author{
HICRAN ATATANIR / KASIM KARATAŞ
}

Abstract: Poverty is a violation of the human right to live and continues its existence with the protection of the permanent inequalities. In today's consumer society practice, the right to life for people with health problems due to excessive consumption is at risk, as well as people who do not have the income to cover a minimum of goods and services. With the globalization process, expanding neoliberalism threatens the right of every human being to live a life worthy of dignity while the deepening inequalities rapidly transform people and their lives. The steps that need to be taken in order to take the place they deserve in the social life as individuals who can use, defend and develop the rights of the poor masses concern the human family and its future directly and closely. Thus, one of the ways to eliminate poverty permanently and for all, is to approach the issue with rights-based approach. In this study, while poverty is considered as a social problem that deepens the rights violations, the right-based approach to the fight against poverty has been tried to be evaluated in terms of education, work, development and resistance rights which are considered to have a determining and functional effect in the neoliberal transformation process.

Keywords: Poverty, Human rights, Right based approach. 